\title{
Toros Yayla Köylerinde Sinema Deneyimleri: Modernlik, Şehir, Sinema Ve Seyirci İlişkilerine Dair Bir Soruşturma ${ }^{1}$
}

\author{
Aydin Çam* \\ İlke Şanlıer**
}

\section{Özet}

$\mathrm{Bu}$ çalışma, anaakım sinema tarihi araştırmalarının geleneksel yöntemlerinden belirgin biçimde ayrllarak, Yeni Sinema Tarihi yaklaşımından hareketle 1960-1980 yılları arasında, Adana'ya 170, Mersin'e 70 kilometre mesafede ve yaklaşık 1.500 metre rakımda konumlanan Toros yayla köylerindeki sinema deneyimlerini merkezine almaktadır. Temel amaç, bahsi geçen dönemde salonlarda ya da seyyar sinemalar aracılığıyla Toros yayla köylerinde gerçekleşen seyir deneyimlerini araştırmak; eğer yaşandıysa, sinemayla birlikte gerçekleşen kültürel değişimleri/dönüşümleri saptamak ve çözümlemektir. Bu bağlamda bazı araştırma soruları şöyle sıralanabilir: (1) 1960-1980 yılları arasında Toros yayla köylerinde film gösterimleri hangi mekânlarda, hangi koşullarda ve hangi etkinliklerle gerçekleştirilmiştir? (2) Gerçekleştirilen gösterimlere kimler katılmıştır ve bu katılımcıların seyir deneyimleri nelerdir? (3) Bahsi geçen dönemde, yayla köylerindeki seyir deneyiminin gündelik hayattaki yansımalarn nelerdir? (4) Sinemayla birlikte, bahsi geçen köylerde bir kültürel dönüşüm yaşanmış mıdır? Ĕ̆er yaşandıysa bu dönüşümü nasıl tanımlayabiliriz? Araştırmayı gerçekleştirmek için yazar ve senarist Osman Şahin'in çalışmalarından hareketle seyyar sinemacılarn film gösterimi yaptıkları izlekler çıkarılarak yayla köyleri belirlenmiştir. Araştırmanın gerçekleştirileceği köylerin belirlenmesinde Osman Şahin'in 1974'te Yedinci Sanat dergisi için gerçekleştirdiğ “ “Toros Dağları'nda Sinema Soruşturması" adlı söyleşide konuştuğu seyyar sinemacı Musa Özder'in ifadelerinden yararlanılmıştır. Buradan hareketle araştırma, Mersin ili sınırları içinde bulunan Toros yayla köylerinde 1960-1980 yılları arasında yapılan seyyar sinema gösterimlerini izlemiş, 1970 yılı ve öncesinde doğan katılımcılarla sözlü tarih yöntemiyle gerçekleştirilmiştir. Araştırma sonucunda bahsi geçen köylerdeki sinema etkinliklerinin, seyir mekânlarının ve deneyimlerinin, Batıl geleneksel/konvansiyonel sinema çalışmalarının önermelerinden son derece farklı biçimlerde gerçekleştirildiği görülmüştür ve çalışmada bu farklilıklar değerlendirilmektedir.

Anahtar Kelimeler: Çukurova Bölgesi Sinema Tarihi, Yeni Sinema Tarihi, Seyirci Deneyimleri, Köy Sinemaları, Seyyar Sinema

ORCID ID : 0000-0002-4168-3093 \& 0000-0002-0971-3379

E-mail : aydinaksu@gmail.com; ilkesanlier@gmail.com

DOI: $10.31122 /$ sinefilozofi.514088

Geliş Tarihi - Recieved: 17.01.2019

Kabul Tarihi - Accepted: 15.04.2019

1 Bu çalışma Çukurova Üniversitesi Bilimsel Araştırma Projeleri Koordinasyon Birimi tarafından desteklenen SBA-2018-10631 kodlu ve Sinema Çerçileri - Toros Dağlarında Seyyar Sinema Deneyimi başlıklı bireysel araştırma projesi kapsamında gerçekleştirilmiştir. Çalışmanın ilk hali 23-25 Kasım 2018 tarihleri arasında Akbank Sanat Beyoğlu / Ístanbul'da gerçekleştirilen 1. Ulusal Sinema ve Felsefe Sempozyumu'nda Sinema Çerçileri - Toros Dağlarında Sinema Deneyimi başlığıyla sözlü bildiri olarak sunulmuştur. 


\title{
Experiences of Cinema in Taurus Highland Villages: A Query on the Relations of Modernity, City, Cinema, and Audiences
}

\author{
Aydın Çam* \\ İlke Şanlıer**
}

\begin{abstract}
Drawing apart from the traditional methods of mainstream cinema history research and based on the New Cinema History approach, this research focuses on the cinema experiences of Taurus highland villagers located at an altitude of approximately 1.500 meters and at a distance of about $170 \mathrm{~km}$ to Adana and about $70 \mathrm{~km}$ to Mersin from 1960 to 1980. The main objective is to explore the cinematic experiences of the villagers of Taurus highlands through travelling cinema and/or cinema halls, and to identify and analyze the cultural changes/transformations that took place through cinema. In this context, some research questions can be listed as follows: (1) In which places and under what occasions did the film screenings take place in Taurus highland villages between 1960 and 1980? (2) Who had participated to the screenings and what were the moviegoing experiences of these participants? (3) What were the reflections of the moviegoing experiences in the daily life of highland villagers? (4) What were the contributions of cinema to cultural transformation in these villages? If there were any, how can we define these transformations? In order to carry out this study, we identified the highland villages to research from the works of writer and scriptwriter Osman Şahin. In the selection of the villages, we followed the route of Musa Özder, a travelling film exhibitor, and his statements in an interview entitled "Cinema Investigation in the Taurus Mountains," conducted by Osman Şahin in 1974 for the Yedinci Sanat magazine. Hence, we conducted oral history interviews with villagers who were born in or before 1970 and lived in Taurus plateau villages within the borders of Mersin province between 1960 and 1980. Based on our findings, we conclude with a discussion of how the cinema activities and places, and moviegoing experiences in these villages may direct us to quite different paths from the Western notions of audience in traditional/conventional cinema studies.
\end{abstract}

Keywords: Cinema History of Çukurova Region, The New Cinema History, Experiences of Audiences, Rural Cinemas, Travelling Cinema

ORCID ID : 0000-0002-4168-3093 \&0000-0002-0971-3379

E-mail : aydinaksu@gmail.com; ilkesanlier@gmail.com

DOI: 10.31122/sinefilozofi.514088

Recieved - Geliş Tarihi: 17.01.2019

Accepted - Kabul Tarihi: 15.04.2019 


\section{Giriş}

\section{Felsefi Bir Etkinlik Olarak Seyir Deneyimini Soruşturmak}

"Hayat çok yönlüdür, tarih de öyle..."

Felsefe sözcüğ̈ünün karş1lı̆̆1 olarak Türk Dil Kurumu tarafından yayınlanan Güncel Türkçe Sözlük'te (www.tdk.gov.tr) önerilen bazı tanımlar şunlardır: “(1) Gerçeğin (realitenin) tümünü, özdek ve yaşam ile ilgili türlü belirtileri neden, ilke ve erekler bakımindan inceleme amacı taşıyan düşünce etkinliği; (2) Bilgi, kavram, inanç ve kuramların çözümlenmesi ve eleştirilmesinde açıklık arayan düşünme yöntemi; (3) Genel olarak mantık, ahlâk, estetik, fizikötesi ve bilgi kuramı gibi dallardan oluşan geniş bilim alanı." Buradan hareketle felsefeyi ve felsefe yapma etkinliğini, gerçeğin/gerçekliğin ilke ve erekler bakımından incelenmesi ve bunu yaparken de bilgi, kavram, inanç ve kuramların çözümlenmesi ve eleştirilmesinde açılık arayışı olarak özetleyebiliriz. Tüm bu etkinlik sırasında olguların mantıkî, ahlaki, estetik, metafizik, ontolojik ve epistemolojik boyutlarını gözetmemiz ve doğal olarak felsefî güdüyle tetiklenen merakımızı örgütlememiz gerekir. Nihayetinde felsefe ancak ve ancak örgütlenmiş bir merakla hâsıl olabilir, tıpkı sinema gibi. Evet, filmler bir yandan kendi başına felsefe yaparken, diğer yandan "hem hayatın içinde yer alan hem de hayattan taşan unsurları yakalama anlamında verili hayatların dışına çıkan, iki dünya arasında çatallanmalar yaratan, iki dünya arasında gidip gelerek yeni oluşlar yaratan bir felsefe üretmektedir" (Öztürk, 2018: 25). Ama takdir edersiniz ki hem film üretimi hem de bir filmden yola çıarak farklı yaşamlar, olgular, fenomenler, zamanlar ve mekânlar arasında bağlantı kurma girişimi ancak örgütlenmiş bir merakla mümkün olabilir. Örgütlenmiş bir merak ve disiplinli felsefe yapma girişimi bize olguları yeni biçimlerde yorumlama ve dünyaya başka bir biçimde bakma olanağı sağlar. Bunların yokluğu ise öncül veriyle yetinerek basmakalıp fikirlerin tekrarına, ön kabullere, önyargılara, birörnekleştirme girişimlerine ve kanaatlerin hakikate dönüşerek yenilenmesine yol açar: Elinde çekiç olan kişi, bir süre sonra her meseleyi çivi gibi görmeye başlar. Oysa felsefe yapma niyeti, ilk elden çekiçten şüphe eder.

Biz bu çalışmada, Toros yayla köylerinde 1960-1980 yılları arasında gerçekleşen seyir deneyimlerinin de sinematik felsefenin bir alanı olduğunu düşünerek, seyir deneyimine dair Batılı geleneksel/konvansiyonel önermeleri soruşturmayı denemekteyiz. Tarihsel olarak sinema alanındaki akademik yazın, şehirleşme ve modernleşme ile doğrudan ilişkilendirilen, yalnızca metropol-merkezli bir deneyim olarak sinemayı araştıran, Batılı geleneksel/ konvansiyonel bakışla yürütülen çalışmaları ağırlıklı olarak içermektedir. Oysaki sinema üretim, dağıtım ve gösterim ile seyir deneyimi şehir ya da sinema salonu gibi mekânsal sınırları aşan çok-katmanlı bir toplumsal ilişkiler ağını kapsar. Bu ilişkiler ağını anlayabilmenin yolu da sinema seyir, mekân ve gösterim deneyimlerini merkez-dışı, şehir-dışı, hareketliliği kapsayan, sınırların daha geçirgen olduğu deneyimler biçiminde düşünebilme ve tahayyül etme çabasını gerektirir. Fernand Braudel'in öndeyişte andığımız sözü tam da bu amacı hatırlatır niteliktedir: Sinema seyir deneyimi çok yönlüdür, tarihi de öyle. Bu bağlamda, Toros yayla köylerinde 1960-1980 yılları arasında vuku bulan sinema seyir deneyimlerine ilişkin yürüttüğümüz araştırmamızdan elde ettiğimiz bulgular ve elinizdeki makalede sunduğumuz 
modernlik ve şehir-dışı seyir pratiği tartışması, Türkiye' de kalıplaşmış sinema tarihi bilgisinin çok ötesinde deneyimlerin de gerçekleştiğini göstermektedir. Biz de bu çalışmada öncelikle Toros yayla köyleri gibi özgün bir yerel coğrafyada tarihsel bir araştırma yapmanın yöntemsel boyutlarını tartışıp, ardından sözlü tarih çalışmalarıyla derlediğimiz bulgularla şu sorulara Yeni Sinema Tarihi (Maltby, Biltereyst \& Meers, 2011; Biltereyst \& Meers, 2016; Biltereyst, Maltby \& Meers, 2019) perspektifiyle yanit aramaktayı: (1) 1960-1980 yılları arasinda Toros yayla köylerinde film gösterimleri hangi mekânlarda, hangi koşullarda ve hangi etkinliklerle gerçekleştirilmiştir? (2) Gerçekleştirilen gösterimlere kimler katılmıştır ve bu katılımcıların seyir deneyimleri nelerdir? (3) Bahsi geçen dönemde, yayla köylerindeki seyir deneyiminin gündelik hayattaki yansımaları nelerdir? (4) Sinemayla birlikte, bahsi geçen köylerde bir kültürel dönüşüm yaşanmış mıdır? Eğer yaşandıysa bu dönüşümü nasıl tanımlayabiliriz? Bu sorularla yürütülen araştırmanın temel bulgularının özellikle seyir deneyimleri bağlamında ve modernlik, şehir, sinema ve seyir ilişkisine dair Batılı geleneksel/konvansiyonel önerilerle çelişen yönleri ise okumakta olduğunuz bu metne kaynaklık etmektedir. Elinizdeki makalede de, öncelikle araştırma yöntemine dair bilgiyi sunup, ardından çelişkileri ve ikilikleri daha iyi betimleyebilmek amacıyla kuramsal ve kavramsal çerçeve ile bulguları bir arada ilişkilendirerek sunuyoruz.

\section{Araştırmanın Yöntemi: Yeni Sinema Tarihi Çalışmaları ve Sözlü Tarih}

Yeni Sinema Tarihi çalışmaları ve yazımı için bellek ve arşiv özellikle merkezi bir önem taşımaktadır; bu nedenle film ve yönetmen odaklı bir sinema çalışmasından çok, sinema seyir deneyimini de kapsayacak şekilde tüm üretim ve tüketim pratiklerini içeren bir çalışma alanı oluşmuştur. Seyir deneyimini toplumsal bir deneyim/etkileşim alanı olarak ele alan Yeni Sinema Tarihi yaklaşımı, film tarihindense daha bütüncül bir sinema tarihi anlayışını kapsar. Bu alana dair bilgiyi üretmede elbette yazılı ve görsel arşiv materyallerinin önemi yadsınamaz. Ancak tüm bu materyallerden daha çok, hâlâ hatırlanabilir bir dönemi incelediği için yeni sinema çalışmaları, sözlü tarih yöntemini hem epistemolojik hem de yöntemsel olarak öncelikli kullanır. Hatta sözlü tarih çalışmalarının öncülleri arasında sinema tarihine ilişkin araştırmaların da bulunması ilginçtir. Kevin Brownlow'un (1968), 1916-1928 yılları arasında Amerikan sessiz sinemasını konu alan çalışması The Parade's Gone By... sinema alanında olmasının dışında, genel olarak sözlü tarih yönteminin ilk örneklerindendir. Sözlü tarih çalışmaları, 'büyük bir çoğunluğun yaşamını biçimlendiren olayların aslında sıradan, günlük olgular olduğunu' önerir. Dolayısıyla özgün ve sıra dışı vakalardan çok gündelik yaşama dair olgular özellikle sözlü tarihçinin konusudur. Böylelikle sözlü tarih, Stephen Caunce'nin de (2001: 20) belirttiği gibi, "tarihi herkese açmaya yönelik bir araca” dönüşerek alternatif bir tarih bilgisinin üretilmesini sağlar. Tarihin alternatif olma iddiası, yalnızca ne söylendiği değil, aynı zamanda tarihi olanın nasıl söylendiğiyle de ilgilidir. Örneğin şehir, metropol ya da iktidar merkezli tarihyazımı pratiğine alternatif olarak çeperde, kırsalda ya da yerelde iktidar sahibi olmayanın, sıradanın tarihini yazmak gibi. Sinema tarihyazımında dolaysız deneyimin ve tanıklığın önemi kadar, bu deneyimlerin nerede yaşandığı da önemli olabilmektedir.

Yerel coğrafyalarda insanların gündelik yaşam pratikleri ile doğrudan ilişkilenmiş seyir deneyimlerini araştırmada sözlü tarih yöntemi, sinema tarihyazımında başat bir önem taşımaktadır. Richard Maltby'nin Biltereyst ve Meers ile derlediği Explorations in New Cinema History: Approaches and Case Studies (2011) başlıklı çalışma Yeni Sinema Tarihi ve yeni sinema 
tarihyazımında sözlü tarihin kullanımı üzerine pek çok araştırmayı içermektedir. Amerika Birleşik Devletleri'nde farklı yerel coğrafyalarda sinema seyir deneyiminin değerlendirildiği Going to the movies: Hollywood and the social experience of cinema (Maltby, Stokes ve Allen 2007) başlıklı derleme de oldukça önemlidir. Başka bir coğrafyada, Hindistan'da, sinema seyir deneyiminin toplumsal boyutları üzerine doktora tezi ve araştırma çıtıları ile Lakshmi Srinivas (1998, 1999 ve 2002), kapsamlı ve şimdiye kadar akademik yazında kabul görmüş olanın dışında bulgular sunmaktadır. Daniela Treveri Gennari, Hipkins ve O'Rawe'ın (2018) sinema çalışmalarında coğrafi kategorilerin kullanımını sorguladıkları ve sinemayı ontolojik olarak şehir merkezinden çıkaran araştırmaları içeren derlemesi de yerel sinema tarihyazımı örnekleri arasında anılmalıdır. Türkiye'de de gittikçe zenginleşen böylesi tarihyazımı anlayışıyla üretilmiş, Anadolu şehirlerinin sinema tarihini ve bu şehirlerdeki sinemaya gitme deneyimlerini merkezine alan örnekleri önemli bulmaktayız. Örneğin Oğuz Makal (2002) ve Dilek Kaya (2017), eski İzmir sinemalarını; Hakan Aydın (2008), 1910-1950 yılları arasındaki Konya sinemalarını; Arzu Ertaylan (2013), Yeşilçam dönemi Van sinemalarını; Ali Sait Liman (2014), 1923-1980 yılları arasındaki Gaziantep sinemalarını; Meltem Özkan Altınöz (2015), Karabük' ün endüstrileşme döneminde ilçede faaliyet gösteren Yenişehir Sineması' nı incelediği araştırmalarında yerel bilgi ve deneyimi derlemiştir. Ankara sinemalarını ve bu şehirdeki seyir deneyimini inceleyen çalışmalar (örneğin Karagözoğlu, 2004; Evren \& Karadoğan, 2008; Mungan Yavuztürk, 2013; Öztürk, 2013) hem mekânsal deneyimler hem de seyredilen filmlerin alımlanması açısından çok değerli bulgular sunar. Halen devam etmekte olan iki çalışmadan da söz etmek gerekir: Yektanurşin Duyan'ın, 1960-1980 yılları arasında Mardin'in şehir merkezinde yaşayan kadınların sinemaya gitme deneyimlerini ve sinemayla kurdukları ilişkiyi irdeleyen sözlü tarih çalışması ile Ayşe Toy Par'ın yürüttüğü ve 1940'lı yıllarda taşrada yaşayan kadınların sinemaya gitme deneyimlerini içeren araştırması Türkiye'deki Yeni Sinema Tarihi yazımına çok önemli katkılar sağlayacaktır. Son olarak, çok-mekânlı ve çok-katmanlı bir araştırma olarak tasarlanan, yürütücülüğünü Hasan Akbulut'un yaptığı, Ruken Öztürk, Emine Uçar İlbuğa ve Mert Gürer' in araştırma ekibinde yer aldığı TÜBİTAK destekli Kültürel ve Toplumsal Bir Pratik Olarak Sinemaya Gitmek: Türkiye'de Seyirci Deneyimleri Üzerine Bir Sözlü Tarih Çalışması başlıklı proje, İstanbul, Ankara, Kocaeli ve Antalya' daki seyir deneyimlerinden hareketle, 1960-1980 yılları arasında sinema kültürünü, sinemaya gitme deneyimini sözlü tarih yöntemi aracılığı ile ortaya koymaktadır. Bu projenin akademik (örneğin Akbulut, 2017; Akbulut, 2018; Uçar İlbuğa, 2017 ve Uçar İlbuğa, 2018) ve sanatsal/belgesel çıtıları çalışmalarımız için ilham verici niteliktedir.

Yukarıda benzer örnekleri sıraladığımız araştırmamız için ise özellikle Osman Şahin'in Toros dağlarında film satan sinema çerçileriyle ve seyircilerle gerçekleştirdiği, 1974 yılında Yedinci Sanat dergisinde yayımlanan “Toros Dağları' nda Sinema Soruşturması" adlı çalışması esin kaynağı olmuştur. Öncelikle bu soruşturmada adı geçen altı köyde (Arslanköy, Yavca, Kavaklıpınar, Tırtar, Çağlarca ve Yüksekoluk) seyyar sinemacıların ve seyircilerin peşine düşmeyi hedeflediysek de, araştırmamız anlatılarla desteklendikçe söz konusu altı köyle sınırlı kalmadı. Saha araştırmasını ve derinlemesine görüşmeleri Arslanköy, Ayvagediği, Fındıkpınarı, Gözne, Kargıpınarı, Kızılbağ, Yavca köyleri ile Adana ve Mersin şehir merkezlerinde Temmuz-Aralık 2018' de gerçekleştirdik. Her ne kadar yedi köyde görüşmeler yaptıysak da Toros dağlarındaki yaklaşık 40 köyde gerçekleştirilen sinema etkinliklerine ve seyir deneyimine dair anlatıyı derledik. Araştırmamız boyunca verilerimizi yapılandırılmamış ya da yarı-yapılandırılmış derinlemesine görüşmelerin yanı sıra gözlem, yerel gazete arşivleri, 
merkezi meclis tutanakları, yerel yönetimlerin kayıtları ve görsel materyaller gibi diğer kaynaklarla çeşitlendirdik. Bu makalede özellikle, seyir deneyimlerine ilişkin derinlemesine görüşmelerden elde ettiğimiz bulguları sunuyoruz. Saha araştırması boyunca 7 kadın, 32 erkek olmak üzere toplam 39 kişiyle derinlemesine görüşme yaptık. Katılımcılarımızın üu̧ü seyyar sinemacı ve ikisi sinema işletmecisiydi. Katılımcıların doğum tarihleri 1933 ile 1970 yılları arasında değişirken, yaş ortalamaları 63'tür. Her ne kadar araştırmamızın konusu sinema seyir ve gösterim deneyiminin 1960-1980 yılları arasındaki dönemini belgelemek olsa da, toplumsal, siyasal ve ekonomik bağlamı anlamamız açısından tarihsel anlatıyı mümkün olduğu koşullarda 1940’ların ortasına kadar geriye taşıyabildik.

Tüm saha çalışmalarımızı Çukurova Üniversitesi İletişim Fakültesi - Radyo, Televizyon ve Sinema Bölümü'nde lisans eğitimine devam eden beş öğrencimizle birlikte yürüttük. Bu sayede araştırma yapmayı eğitim etkinliklerinin bir parçası olarak değerlendirdiğimiz için zanaatı aktarma fırsatını da bulduk. Sahada öğrencilerimizle beraber araştırmayı yürütmek, yöntemsel açıdan iki önemli yarar sağladı. Öncelikle katılımcılarımız, genç arkadaşlarımızın öğrenme merakı karşısında geçmiş deneyimlerini aktarma konusunda daha hevesli oldular; daha çok hatırlama çabası içine girdiler. Bu sözlü tarih derlemesi için verimizin zenginleşmesi anlamına geldi. İkinci olarak ise sözlü tarihin sunduğu eşitlikçi olanaklar, bizim araştırmacı olarak bilgi toplayan rolümüzü hem katılımcılarımız hem de öğrencilerimizle eşitledi; dolayısıyla hem kendimize hem de araştırma konusu ve sürecine yeniden bakmamızı sağladı. $\mathrm{Bu}$ ise tarihyazımı deneyiminin diğer sosyal bilim araştırmalarından biraz daha farklılaşarak araştırmacının sorumluluğuna dair yeni sorgulamaların da önünü açtı. Tam da buna bağlı olarak ifade etmeliyiz ki, her ne kadar araştırma ve raporlama etiğinin ilkelerinden biri katılımcıların kimliklerinin anonim olarak korunması olsa da, çalışmamızın sinema tarihine ve yerel tarihe katkıları, katılımcıların yaşantılarının ve deneyimlerinin görünür kılınması ve tevdi edilmesi, araştırma güvenirliğinin güçlendirilmesi ve sosyo-politik bir dönüşüme olanak vermesi nedeniyle benzer sözlü tarih çalışmalarında (Roux, 2015) olduğu gibi bulgularımızı katılımclarımızın onayını alarak gerçek isimleri ile sunmaktayız. Braudel'in "tarihin çok yönlülüğ̈̈" önermesinin, yalnızca tarihi yazanların değil tarihi yaşayanların da isimlerini teslim ederek geçerli olabileceğine inanyoruz. Elbette ki sözlü tarihçiler olarak, sözlü tanıklıklardan yararlanarak giriştiğimiz bu tarih yazma çabasında tanıklıklardan edindiğimiz bilgileri tartma sorumluluğunu üzerimize almaktayı.

\section{Modernlik, Şehir, Sinema ve Seyir(ci) İlişkisine Dair Temel Önermeler, Araştırma Bulguları ve Değerlendirmeler}

Batılı geleneksel/konvansiyonel yaklaşımda şehir ve sinemanın modernlikle güçlü bağları olduğu önerilmektedir. Bu üç olgu arasında simbiyotik bir ilişki vardır: Şehir (ve şehirli olmak), sinema (ve seyir) ve modernlik üçlü bir ilişkiyle birbirlerine bağlıdır. Modern şehrin ve sinemanın doğuşu aşağı yukarı eş zamanlıdır; şehir ve sinema bir bakıma modernliğin kahramanlarıdır (Öztürk, 2007: 22). Zaten sinema neredeyse tüm coğrafyalarda, özellikle de o coğrafyadaki ilk yıllarında varlığını şehirlerde bulmuştur. Örneğin Walter Benjamin (2007: 72), sinemanın şehrin karabasana dönmüş yaşamında radikal bir değişim yarattığını söyleyerek henüz erken dönemde bu ilişkiye dikkatimizi çeker: "Bir zamanlar içkievlerimizin ve büyük kentlerdeki caddelerin, bürolarımızın ve möbleli odalarımızın, tren istasyonlarımızın ve fabrikalarımızın arasına umutsuzca hapsolmuş $\square$ gibiydik. Daha sonra sinema geldi ve zindandan oluşma bu dünyayı saniyenin onda biri uzunluğundaki zaman parçacıklarının 
dinamitiyle paramparça etti; şimdi bu dünyanın geniş bir alana dağılmış yıkıntıları arasında serüvenli yolculuklara çıkmaktayız." Sinemanın paramparça ettiği eski şehirlerin -dolayısıyla eski yaşam biçiminin- yerini yenileri almaktadır ve sinema seyircisi de bu yeni şehirlerde varlığını bulan kentsoylu bir topluluktur. Öyle ki, 1900'lerden itibaren yaşanmakta olan bu yeni dönemi Film Çă̆ı olarak adlandıran Arnold Hauser'e göre, ortaya çıkan bu yeni şehirli topluluk ancak sinema seyircisi olmakla nitelendirilebilmektedir. Hauser (1995: 423), "Filmcilik kazandığı büyük başarıyı, küçük kentsoylu sınıfının isteklerinin, kitlelerin psikolojik buluşma yeri olduğunu fark etmesine borçludur" der. Orta sınıf, işçi ordusuyla, küçük memurlarıyla, özel büro hizmetlileriyle, gezici satıcılarıyla ve çıraklarıyla sınıflar arasında gidip gelerek çimentosunu filmin oluşturduğu yeni bir sınıf meydana getirir: Bu, küçük kentsoylu yeni orta sınıftır. Tabii ki sinemayla şehri ve şehirli olmayı ilişkilendiren bu ve benzeri önermeler hiç de dayanaksız değildir. 1900'lerin başından itibaren farklı coğrafyalarda özellikle metropollere akın eden kitleler, sinemanın yarattığ kamusal alanlarda bir araya gelme ve toplumsallaşma fırsatı bulmuştur. Yirminci yüzyılın başında sadece Paris, Berlin, Viyana ya da Londra gibi Avrupa metropollerinde değil, İstanbul, Kahire, Kalküta ya da Moskova gibi dünyanın farklı coğrafyalarındaki metropollerde de sinema gündelik hayatın merkezindedir.

Bundan dolayıdır ki yakın zamana kadar sinema tarihyazımının merkezinde metropoller yer almıştır. Hatta bu tarihyazımında, metropollerin ya da diğer şehirlerin merkezlerinin dışında bir sinema seyir etkinliğinin gerçekleşmiş olmasına dahi ihtimal verilmediği olmuştur. Örneğin Esra Biryıldız, Fransa'da Pathé Frères aracılığıyla ve seyyar sinemacılık etkinlikleriyle, gösterimlerin hemen ilk yıllardan itibaren şehir dışına taşındığını söyler ve ekler: “Ancak [bu] günlere özellikle Türkiye' de hiç ulaşılamamıştır; filmler ancak kentlerdeki sinema salonlarında izlenebilir durumdadır (...) Kentsel bir olgu olarak ortaya çıkan cafelerdeki gösterimlerle başlayan sinema, Pathé'nin aracılığı ile kent dışına çıkmıştı ancak sinemanın gelişimi, yaşanan ekonomik ve toplumsal koşullar özellikle ülkemizdeki sinemayı kentlere mahkûm etmiştir" (Biryıldız, 2004: 55). Oysa hem farklı çalışmalar hem de Adana şehir merkezi ve Toros yayla köylerinde gerçekleştirdiğimiz araştırmalar bize, ulusal sinema tarihimizin ilk günlerinden itibaren İstanbul dışında seyyar sinemacılık etkinliklerinin gerçekleştirildiğini, Anadolu'daki bu seyyar gösterimlerin kısa sürede şehirlerde kalıcılaştığını ama şehir dışında da seyyar sinemacılığın yoğun biçimde sürdürüldüğünü göstermektedir. Örneğin 1902'de, Anadolu'daki film gösterimlerinin çoğunlukla seyyar sinema makineleriyle gerçekleştirildiği bir dönemde, Yunanistan'dan gelen bir sinematografçı, önce Mersin'de hemen ardından da Adana' da film gösterimleri yapmıştır (Özuyar, 2013: 150). Bunun ardından 1910'larda Adana ve Mersin'de ilk sinema salonları düzenli gösterimlere başlamıştır. 1924 tarihli Adana Ticaret Rehberi'nde (Oğuz, 2014: 97) şehirde düzenli olarak sinema gösterimleri yapan iki sinemanın kaydı bulunmaktadır. 1940'ların ikinci yarısında, İkinci Dünya Savaşı'nın hemen ertesinde Adana ve Mersin'in şehir merkezlerine en uzak dă̆ köylerinde dahi seyyar sinemacilar aracılığıyla film gösterimleri gerçekleştirilmiştir. 1947'de Mersin'e 70 kilometre mesafede ve yaklaşık 1.500 metre rakımda konumlanan Arslanköy'de, Çukurova Bölgesi'nde bulunan Amerikan askeri personelinin teknik desteğiyle ilk film gösterimi yapılır. Sadece bir yıl sonra bu kez katır sırtında taşıdıkları projektör ve jeneratörleriyle gelen sinema çerçileri köyde film gösterir (Şahin, 1996: 301-307). 1960'lardan itibaren Arslanköy'de hem açık havada hem de Halkevi'nin sağladığı bir salonda, daha önce seyyar sinemacılıkla hayatlarını kazanan Musa Özder ve kardeşi Mehmet düzenli film gösterimleri yaparlar. 1972'de ise Sami Dündar ve oğulları Nazım ve Ömer köyün ikinci salon sineması olan 300 koltuklu Arı Sineması'nı faaliyete 
geçirir. Bu dönemde, araştırmanın gerçekleştirildiği köylerden Arslanköy, Güzelyayla (Kızılbağ), Gözne, Ayvagediği, Kargıpınarı ve Fındıkpınarı'nda düzenli film gösterimlerinin yapıldığı salon, açık hava, teras/dam, bahçe ve yayla sinemaları bulunmaktadır. Bununla beraber başta Tırtar, Yavca, Değnek, Değirmendere ve Dalakderesi olmak üzere, neredeyse her yayla köyünde seyyar sinemacılar aracılığıyla film gösterimleri yapılmaktadır. Aynı dönemde bu bölge film çekimlerine de tanıklık eder. Dolayısıyla Toros yayla köylerinde, özellikle 19601980 yılları arasında son derece devingen bir sinemacılık etkinliği gerçekleşmiştir.

Aslında geleneksel/konvansiyonel yaklaşımda sinema ve seyrin modernlikle ilişkisi, şehir aracılığı olmadan da güçlü bir biçimde kurulmaktadır. Öncelikle sinemanın doğrudan modernliğin sanatı olduğu, hiçbir sanatın modernliği ondan daha iyi temsil edemeyeceği önerilir. Mario Pezzella'ya (2006: 11) göre sinema, modernitenin sembolik sanatıdır. Jean-Paul Sartre'a göre de sinema zamanın temsilinin en aşikâr aracıdır. Sartre'a göre, sinema uygarlığ1 yansıtan bir sanattır ve insana "içinde yaşadığı dünyanın güzelliğini, süratin, makinaların şiirini ve sanayinin insanlık dışı muhteşem kaçınılmazlığını" öğretmektedir (Sartre'dan aktaran Harvey, 2010: 233-234). Eric J. Hobsbawm (1999: 259) hiçbir sanatın, "tamamen gelenek dışı olan sanatsal bir modernizmin gereklerini ve amaçlanmamış zaferini sinemadan daha dramatik biçimde temsil edemeyeceğini" söyler. John Orr (1997: 32) ise sinema ve modernlik ilişkisini daha da ileri bir düzeye taşıyarak sinemanın, "yenilikçi bir biçim olarak, hem modern sanat yapıtının uzlaşımlarına hem de modernliğin kendisine meydan okuduğunu" ileri sürer. Öyle ki sanat olarak sinemanın modernlikle ilişkisi kadar seyrin de modernlikle ilişkisi güçlü biçimde kurulmaktadır. Sözünü ettiğimiz literatürde sinemaya gitmek, modern şehir yaşamının en önemli etkinliğidir ve bir bakıma sinemaya gitmek modernliğin bir gereğidir. Bundan dolayıdır ki Türkiye İstatistik Kurumu (TÜIK) gibi kurumlar düzenli aralıklarla tiyatro ve sinemaya gitme verilerini derler ve yayımlar. TÜIK tarafından sinema verisinin tiyatro verisiyle bir arada sunulması başlı başına onun üst kültüre ait bir sanat dalı kabul edilmesiyle ilintilidir. Hâlihazırda bu iki veri TÜİK tarafından Kültür İstatistikleri ana ayrımının altında kamuya sunulmaktadır. Yani bu paradigmaya göre, modern bir sanat olan sinemayı takip etmek ve sinemaya gitmek, şehirli olmanın bir gereği, kültürlü olmanın da bir imleyenidir.

Toros yayla köylerinde gerçekleştirdiğimiz araştırmalar sırasında, katılımcıların genellikle şehirlere, özellikle de metropollere atfedilen bazı nitelemeleri kendi köyleri için kullanmış olmaları dikkat çekidir. Örneğin Bilal Ay (13 Temmuz 2018 tarihli görüşme) Arslanköy'ün sakinlerinin sadece Yörükler'den değil, Çukurova Bölgesi başta olmak üzere Anadolu' nun çok farklı yerlerinden gelenlerden oluştuğunu ifade etmekte ve bu bakımdan köyün son derece "kozmopolit" olduğunu belirtmektedir. Bu nedenle köyün sabit ve seyyar sinemalara ev sahipliği yapması ya da sinema salonlarının konser, tiyatro veya diğer kültürel etkinlikler için kullanılması tesadüf değildir. An Sineması'nın kurucusu olan büyükbabasıyla aynı adı taşıyan, halen Mersin'de yaşayan ama çocukluğunu Arslanköy'de geçiren Sami Dündar da aynı vurguyla Arslanköy'ün eğitimli sakinleriyle, kültürüyle, sineması ve tiyatrosuyla öne çıktığını belirtmekte ve köy için "Kozmopolit. Yapısı çok farklıdır" demektedir (26 Temmuz 2018 tarihli görüşme). Bu bağlamda Sami Dündar'ın sinemadan uzaklaşmayı "kültürel kayıp ve gerileme" olarak nitelendirmesi de önemlidir. Sinemaya gitmek okuryazarlıktan bağımsız bir biçimde eğitimli olmak anlamına gelmektedir. Sabit ve/veya seyyar sinemaların etkin bir biçimde çalıştığı 1960-1980 yılları arasında, köyün şehirle ilişkisinin nadiren kurulduğu bir dönemde, kadınların erkeklerle bir arada film izlemeleri kültürel bir 
etkinlik olarak görülmektedir:

"Sinemaya kadınlı erkekli herkes gelirdi o dönemde. Hiç kimse de yadırgamazdı bunu. Yani o ayrı bir kültür olarak görünmüştü. Şimdiki gibi yani, sinemaya herkes gidebilir. Gitmesinde bir sakınca yok. O dönemde, 70'li yillardan ve kapah bir toplumdan bahsediyoruz, Arslanköy'de özellikle bu, hiçbir şekilde yadırganmamıştır" (S. Dündar ile görüşme, 26 Temmuz 2018).

Araştırmamız sırasında görüştüğümüz katılımcıların neredeyse tamamı, geçmişi özlemle anarak, hem sinema sanatının kendisini hem de seyir etkinliklerini kültürle ve/ veya kültürlü olmakla özdeşleştirmektedir. Aslında bu durum, yukarıda zikredilen kabullere denk düşmektedir: Sinemaya gitmek şehirde ya da köyde, kültürlü olmakla özdeşleştirilir; muhafazakâr bir tutum içinde sinemayı reddetmek ise geri kalmışlık olarak addedilir. Üstelik yine yukarıda anılan film izleme istatistiklerine dayanarak kültürlü olma ya da olmama meselesini göz önünde bulundurduğumuzda, aslında bu köylerde yaşayanların en az şehirliler kadar seyir deneyimine sahip olduklarını söyleyebiliriz. Toros yayla köylerinde Nisan-Mayıs ayları gibi başlayan ve Eylül-Ekim aylarında sona eren yaz sezonunda, ortalama haftada bir kez seyyar sinema gösterimi gerçekleştirilmektedir. Bununla beraber salon sinemalarında, okullarda ya da kahvehanelerde yıl boyu film gösterimleri yapılmaktadır. Sami Dündar, Arslanköy'de Arı Sineması'nda yıllarca her gün 300-400 seyircinin katılımıyla film izlendiğini aktarmaktadır. Tüm bunlar bize, sinemanın sadece şehirlere özgü bir olgu olmadığını, en ücra köylerde dahi bu deneyimin yoğun bir biçimde gerçekleştiğini göstermektedir. Dolayısıyla şehir (ve şehirli olmak), sinema (ve seyir) ve modernlik ilişkisi, zorunlu bir ilişki değildir; pekâlâ bu ilişki köyler için de kurulabilir.

1900'lerin başında İstanbul'daki gösterim mekânlarının ve seyir etkinliklerinin günümüzdekinden epey farklı olduğunu söyleyebiliriz. Örneğin, 1909'da yayımlanan gazetelerin ilanlarında Sigmund Weinberg idaresindeki Pathé Frères Sinematograf Tiyatrosu'nun Kadıköy Zamboğlu Bahçesi'nde kadınlara mahsus bir gösterim yapacağı okunmaktadır. Bu gösterimin ince saz takımıyla icra edileceği ve yine aynı yıl Feyziye Kıraathanesi'ndeki diğer bir gösterimin ise kanto ve duettoyla bir arada gerçekleştirileceği benzer gazete ilanlarında yer almaktadır (aktaran Gökmen, 1989: 22). Sadece ulusal değil, uluslararası alanda da sinema gösterimlerinin mekânı, gösterimin yapısını dönüştürecek kadar çeşitlidir. Fuarlar, panayırlar, sirkler, tiyatrolar, barlar ya da kahvehaneler gibi çok farklı mekânlar film gösterimlerine ev sahipliği yapmaktadır. İstanbul'da erken dönem sinema mekânları çoğunlukla kıraathaneler, birahaneler ya da çay bahçeleridir. Film gösterimleri bu mekânların genel-geçer eğlence yapısına uygun bir biçimde, bazen ortaoyunu ya da gölge oyunuyla, bazen ince saz takımının icrasıyla, bazen de bir meddahın gösterisiyle birlikte gerçekleştirilmektedir. Üstelik bu dönemde dil engelleri nedeniyle de sinema mekânları son derece gürültülüdür. Örneğin, bazı sinemalarda film gösterimini gerçekleştiren operatör, yazılar geldikçe bunları seyircilere tercüme etmekte (Fikret Adil'den aktaran Akçura, 2004, s. 204), bazen de tercümenin yanı sıra filmi seyircilere izah etmektedir (Baha Gelenbevi'den aktaran Akçura, 2004, s. 205). Kimi sinemalarda ise okuma-yazma bilmeyenlerin bir tanıdıklarıyla beraber geldikleri ve ısmarlanan sinema bileti karşılığında bu kişinin diyalogları açıkladığı görülmektedir (Eugene Hinkle' den aktaran Özyılmaz, 2006, s. 46). Ama bu durum, sinemanın ilk yıllarında sadece İstanbul'a özgü değildir. İngiltere' de music-hall'lerde, Fransa' da café-concert'lerde ya da Amerika Birleşik Devletleri'nde smoking-concerts'lerde benzer biçimlerde film gösterimleri, diğer eğlence biçimleriyle iç içe geçmiştir. Bu yıllarda seyir, farklı etkinliklerle iç içe ve gürültülü bir biçimde 
gerçekleşmektedir. Ama kısa süre sonra Fransa, Almanya, İngiltere ya da Amerika Birleşik Devletleri'nde, sinemanın henüz onuncu yılında düzenli film gösterimlerinin gerçekleştirildiği salonlar hizmete açılmış, Birinci Dünya Savaşı yıllarında bu salonlar yaygınlaşmış ve salt sinema gösterimlerine özel mekânlar oluşturulmuştur. Aynı dönemde İstanbul'da da başta Beyoğlu olmak üzere, şehrin her yerinde sinema gösterimine özgü salonlar açılmış ve her ne kadar diğer mekânlarda gösterimler devam etse ya da sinema salonlarında tiyatro veya konser gibi farklı etkinlikler yapılsa da, 1930'lardan itibaren bu salonlar birörnek hale gelmiştir. Gerek Batı' da gerekse İstanbul' da birörnekleşen -bir bakıma disipline kavuşan- bu gösterim mekânlarında seyrin de disiplin altına alınması uzun sürmez. Geleneksel olarak seyirciden filmi mutlak bir sessizlikle ve adeta büyülenmiş bir biçimde, huşu içinde izlemesi talep edilir. İzleyicinin gösterim sırasında sessiz, film karşısındaysa görünmez bir tanık olması beklenir:

"[Seyirci] onun varlığını tanımadan akıp giden anlatı karşısında görünmezdir. Bu nedenle de klasik üslupta ne doğrudan izleyiciye hitaba ne de oyuncunun kameraya bakışına yer verilir (...) İzleyici ya görünmez bir tanık konumundadır ya da ondan bağımsız olarak gelişen ancak (sinemanın dışındaki) ortak bir dünyada meydana gelen olaylara sanal bir katılimcı olarak davet edilir" (Elsaesser ve Hagener, 2011: 38).

Oysa seyir sırasında görünmez olmak, başka bir deyişle film karşısında seyircinin edilgen konumda kalması Toros yayla köylerinde pek görülmez.

Toros yayla köylerinde dinlediğimiz seyir deneyimleri bizi Batı yerine Doğu'da yapılan çalışmalarda karşılaştığımız durumlara, örneğin Lakshmi Srinivas'ın $(1998,2002)$ Hindistan'daki çalışmalarına götürmektedir. Srinivas (2002: 160) Hindistan'daki seyrin Batı'daki deneyimlerden epey farklı gerçekleştiğini ifade etmektedir. Örneğin Hindistan'da seyir bireysel değil de bir tür topluluk deneyimi olarak vuku bulmaktadır. Sinemaya bazen arkadaşlardan oluşan bir grupla ya da bazen her yaştan üyenin yer aldığ geniş aileler halinde gidilir. Seyir de şakalaşmaların, bağııış-çağırışların, kahkahaların ve bazen de ağlamaların eşlik ettiği yoğun gürültüyle gerçekleşir. Oysa Batı'da seyir aşırı bireyselleşmiştir ve son derece disiplinli bir eylemdir: Seyirciler sessiz olmalı ${ }^{1}$ ve sadece perdede akıp giden filmle ilişki kurmalıdır. Bu karşılaştırma temelinde, Toros yayla köylerindeki seyir deneyimi Hindistan'dakine son derece benzemektedir. Arslanköy'e yakın yaylalardan sinemaya topluca gidilir. Üstelik hem Arslanköy ya da Yavca gibi köylerin sakinleri hem de bu köylerdeki gösterimlerin potansiyel katılımcıları olan, yakın yaylalarda yaşayanlar büyük ölçüde aynı sülaleye mensup kişilerdir². Salonu ya da gösterimin gerçekleştirildiği alanı dolduran insanların hemen hemen tamamı birbirlerini tanımaktadır. Bu nedenle de sinemaya gitmek, toplanmak olarak addedilir; sinemaya gitmek için toplanılır, gösterim için toplanılır ve gösterimden sonraki günlerde de filmi yeniden anlatmak için toplanılır (F. Ay ile görüşme, 13 Temmuz 2018). Tüm bu toplanma durumuna bağlı olarak, seyir deneyimi gösterimden çok

1 Srinivas (1998: 325), Amerika Birleşik Devletleri'nde seyircinin film karşısında, etnografik bir araştırmayı olanaksız kılacak kadar sessizliğe büründüğünü ve görünmez hale geldiğini ifade etmektedir.

2 Başta Arslanköy olmak üzere, Toroslar'daki yayla köylerinin sakinleri büyük ölçüde, sonradan yerleşik hayata geçen göçerler, Yörük aşiretleridir. Bu nedenle bazen bütün bir köyün sakini tek bir soyadını taşımaktadır. Arslanköy gibi nispeten kalabalık yerleşim yerlerinde dahi, nüfusun büyük oranda iki ya da üç soyadından oluştuğu durumlara sıklıkla rastlanmaktadır. Bununla beraber, daha sonra yerleşik hayata geçen Yörük aşiretlerinin adları -örneğin Köselerliler, Bahşişliler, Sakarlılar ya da Arpaçlılar- mahallelere, köylere ya da semtlere verilmiştir. 
önce başlar ve çok sonra biter. Köye seyyar sinemanın geleceği önceden duyurulmuştur ve tarla ya da bahçelerde çalışanlar büyük bir heyecanla seyre hazırlanmaktadır. Bununla beraber gösterimden saatler önce seyyar sinemacı tarafından plak ya da kasetten şarkılar çalınmaya da başlamıştır (E. Yıldız ile görüşme, 13 Temmuz 2018 ve S. Öz ile görüşme, 28 Ağustos 2018). Seyir, heyecanlı bir hazırlık dönemini kapsar ve bu heyecan gösterim sırasında da devam eder. Gösterimler de son derece heyecanlı ve coşkuludur (M. Kizir ile görüşme, 13 Temmuz 2018); seyirciler heyecandan kâh ayağa kalkar kâh otururlar (S. Öz ile görüşme, 28 Ağustos 2018). Örneğin, filmdeki bir sahnede ezan okunduğunda herkes saygıdan ayağa kalkar (S. Dündar ile görüşme, 26 Temmuz 2018). Sinemayla ilk kez karşılaşanların düştükleri tuhaf durumlara dair yapılan şakalara ve kahkahalara ağlayanların sesleri karışır; bazen bir filmi daha önce izlemiş olanlar, yeniden gösteriminin öncesinde ağlamaya başlar (B. Ay ve F. Ay ile görüşme, 13 Temmuz 2018). Ağlamalar film sirasında, hatta filmden sonra da devam eder. Seyyar sinemacı Hasan Kınalı, kendisinin de sinemada ağlayan kadınlara eşlik ettiğini aktarmaktadır: “Kadınlar ağlar, ben de ağlardım. Lambalar yandıktan sonra, ağlayanlar vardı hep (...) O köylü kadınları görsen hayret edersin” (30 Ağustos 2018 tarihli görüşme). Seyirciler perdedeki kavgalara "Vur lan vur!" diyerek eşlik etmekte, filmin kahramanı kavgadan galip çıktığında tezahüratlar yükselmekte, seyirciler kötü karakterleri islıklamakta, taşlamakta hatta perdeye ateş etmektedir (H. Kınalı ile görüşme, 30 Ağustos 2018 ve Sabri Şenevi ile görüşme, 13 Aralık 2018). Cüneyt Arkın ya da Serdar Gökhan'ın canlandırdığı kahramanlar, bir filmde bayrağ1 alıp kaleye diktiğinde herkes ayağa kalkar ve alkışlar (S. Dündar ile görüşme, 26 Temmuz 2018). Ya da romantik bir sahnede kadın ve erkek karakterler birbirlerine yakınlaştıklarında, örneğin öpüştüklerinde yaşlı kadınlardan itirazlar yükselir: "Dur, dur!" (F. Ay ile görüşme, 13 Temmuz 2018). Dahası, performatif seyir filmden sonra da devam eder: Gösterimin hemen ardından filmdeki sahneler, başta çocuklar olmak üzere, seyirciler tarafından canlandırılır. İzleyenler izlemeyenlere filmi anlatır; bir dahaki seyre kadar misafir sohbetlerinin başlıca konusunu filmler oluşturur. Gösterimden saatler önce başlayan seyir deneyimi, gösterimin ardından bazen günlerce devam eder. Tüm bu süreçte seyirci, film karşısında hiçbir zaman edilgen kalmaz; tersine son derece etkin ve performatiftir. Bu bakımdan da Batılı seyirciyle ve seyir deneyimiyle neredeyse hiç benzerliği yoktur ve daha çok Srinivas'ın $(1998,2002)$ Hindistan'daki seyirciler için dile getirdiği özellikleri taşımaktadır.

Geleneksel/konvansiyonel yaklaşım bunlarla beraber, seyir deneyimine dair ön kabul ve basmakalıp eğretilemelere dayanan bir dizi önerme daha sunar. Bu önermeleri ve onların araştırma bulgularımızla çelişen bağlamlarını şöyle özetleyebiliriz: Özellikle gösterim için düzenlenmiş bir salonda film izlemek, seyirciden gündelik hayatın mekânından ve zamanından azade olmasını talep eden, çoğu zaman tuhaf bir deneyimdir. Film başlamadan hemen önce salonun karanlığa gömülmesi, fizikî gerçekliğin yavaşça ortadan kalkması, mekânın sınırlarının silinmesi ve seyircinin perde düzlemi üzerinde akıp giden imgelerle karşı karşıya kalması gündelik hayatta karşılığını kolay bulamadığımız bir deneyimdir. Bu yüzden de çoğu zaman seyir deneyimi, benzer biçimde gündelik hayatta karşılığı olmayan rüya görme deneyimiyle özdeşleştirilmiştir. Örneğin Thorsten Botz-Bornstein, Filmler ve Rüyalar (2011: 67) adlı çalışmasında "Ekranda cereyan eden olaylar, bir filmin rüyalarla açıkça biçimsel bir benzerlik taşıyor olmasından ötürü, 'seyircinin rüyası' olarak da görülebilir. Seyirci, bir film seyrettiğine inanmak yerine, rüya görüyor olduğuna da inanabilir pekâlâ" demektedir. $\mathrm{Bu}$, seyir deneyiminin ilk günlerinden bu yana seyircinin yüzleştiği yeni fenomen karşısındaki 
durumunu özetleyen bir önermedir. Fransız yönetmen ve eleştirmen Jacques de Baroncelli henüz 1915'te bir seyir deneyiminin ardından, “Bugünlerde, nasıl olduysa, bir utanç keyfimizi kaçırıyor. İnsanlar perdede yüzer gezen imgelere kapılmışlar, gündelik varoluşlarını tamamen geride birakarak, bir rüya ya da bir fantezide sürüklenip gidiyorlar" demektedir (aktaran Abel, 1988: 125-128). 1920'lerde sinema eleştirileri yazan sürrealist şair Robert Desnos da sinema deneyimini sıklıkla rüyayla ilişkilendirmektedir. 1923'te Paris-journal' de yayımlanan Le Rêve et le cinéma (Rüya ve Sinema) başlıklı yazısında, "Arzudan rüyaya geçiş, sinemaya duyulan açlık ve onun aşkıyla mümkün olur. Gündelik hayatımızda yokluğunu hissettiğimiz maceraları, karanlık sinema salonlarında yapay rüyalarla telafi ediyoruz" diyen Desnos (aktaran Abel, 1988: 283-284); 1927' de bu kez Le Soir'de yayımlanan Les Rêves de la nuit transportés sur l'écran (Perdeden Aktarılan Gece Rüyaları) başlıklı yazısında bir kez daha film izleme ve rüya görme deneyimlerini özdeşleştirmektedir: "Sinema salonlarının karanlığı tam da uykudan hemen önceki haliyle yatak odalarımıza benziyor. Perde de belki rüyalarımıza denk düşüyor" (aktaran Abel, 1988: 320). Bu konudaki en olağanüstü benzetimlerden birisi şair, yazar ve eleştirmen Jules Romains'e aittir. Romains, 1911'de yayımladığı La Foule au cinémarographe (Sinematoğraf Karşısındaki Kalabalık) başlıklı yazısında, seyir deneyimini ve seyircinin bu deneyim sırasındaki durumunu son derece ayrıntılı biçimde tasvir eder:

\begin{abstract}
“Başlarını suyun altına sokan bir yüzücü gibiler; gözleri, ağızları ve dişleri sımsıkı kapanmış. Rahatsızlk hatta eziyet veren bir boğulma hissini deneyimliyorlar. Sonra birden tekrar suyun üzerine çıkıyor ve derin bir nefesle hayata geri dönüyorlar. Ansızın, çember şeklindeki bir ışık huzmesi uzaktaki duvarı aydınlatıyor. Bu kez tüm salon aynı anda çı̆̆lı̆̆ basıyor: Açık bir biçimde yeniden doğumun ilk 'hoş geldin' nidası bu. Toplu rüya görme deneyimi şimdi başlıyor. Uyuyorlar; gözleri artık görmüyor. Bedenlerinin bilincinde değiller. Tüm bunlarm yerine, bir rüyanın süzülerek gelip-geçen imgeleri var" (Romains'ten aktaran Abel, 1988: 53-54).
\end{abstract}

Seyir deneyimine dair ilk kanaatlerden ve üretilen eğretilemelerden biri rüyaya dair ise, en az bunun kadar yaygın bir diğeri de mağaraya dairdir. Kaynağını Platon'un mağara alegorisinden alan bir eğretilemedir bu. Platon'un Devlet'inin Yedinci Kitap's bu alegoriden yola çıkan bir soruşturmayla açılır: İnsanlar çocukluklarından itibaren yerin altında, mağaraya benzer bir mekânda yaşamak zorunda bırakılmıştır. Bu mağarada zincirlenmişlerdir ve başlarını her hangi bir yöne dahi çevirmelerine olanak yoktur. Sadece karşılarındaki duvara bakabilmektedirler. Bu esir topluluğununarkasındanveyüksekten bir ateşinışığıparlamaktadır. Ateşle topluluk arasından bir yol uzanmaktadır ve bu yolun üzerinde tıpkı kukla oynatanların seyircinin önüne kurdukları ve üzerinde sanatlarını icra ettikleri tahta perdeye benzeyen alçak bir duvar vardır. Bu duvarın üzerinden ise insanların ve başka yaratıkların tahtadan ve taştan heykelleri, kısaca sanat yoluyla imal edilmiş her şey geçirilmektedir. Esir topluluk, karşısındaki duvarda kendilerinin ve arkalarından geçirilen öteki şeylerin gölgelerinden başka bir şey göremez. Dolayısıyla bu insanlar duvarda gördükleri gölgelerden söz ederken gerçek nesnelerden söz ettiklerini sanmaktadır ve bu gölgelerden başka hiçbir şeyi gerçek yerine koymazlar. Bu eğretileme, sadece hakikat ve sahte hakkında değil, gerçek ve kurmaca ya da gerçek(çi)lik ve biçim(cilik) gibi pek çok ikiliğe dair sinema tarihinin ilk günlerinden bu yana süregiden tartışmaların merkezinde yer alır; bu bakımdan belki de sinema çalışmaları tarihinin en yaratıcı eğretilemelerinden biridir. Üstelik sadece sinemayla da sınırla kalmayarak, değişen imge üretimi tekniklerine de uyarlanabilmektedir (Andersen, 2014: 37). Esirlerin arkalarında bulunan yoldan, duvarın üzerinden taşınan nesnelerin sanat yapıtları değil de dünyaya dair 
farklı imgeler ve idealler olduğunu düşündüğümüzde, gölgelerin televizyon ya da video gibi ortamlarla dolayımlanarak bize sunulan hakikat olduğuna dair şüphemizi nasıl ortadan kaldırabiliriz ki? Ya da güncel hakikat-sonrası çă̆ (post-truth era) önermelerini göz önünde bulundurduğumuzda, medya aracılığıyla kurulan dünyanın Platon'un mağarasından farkı nedir ki?

Sinema salonlarının ve bu salonlarda gerçekleşen seyir deneyimlerinin geleneksel/ konvansiyonel yapısının Platon'un mağara alegorisindeki durumla benzeşen çok yönü vardır: Tıpkı alegoride olduğu gibi, kendilerinden beklenen ve talep edilen disiplinde, tam bir sükunet içinde koltuklarında oturan seyirciler; karşılarında az sonra üzerinden gölgelerin akıp gideceği boş bir perde; arkalarında gölgeleri perdeye düşürmek için kullanılan bir projeksiyon makinesi; gölgelerin daha önce yakalandı̆̆ı ve sabitlendiği pelikül ve gösterimin vuku bulduğu mekân olarak, mağaraya son derece benzeyen, fizikî gerçeklikten yalıtılmış ve sınırları muğlaklaşmış, karanlık salon. Batılı seyir pratiğinde seyirciden talep edilen, mutlak bir biçimde sadece perdeye odaklanması ve perdede süregiden gösteriyi takip etmesidir. Bu bakımdan seyirci tutsak ya da esir olarak da adlandırılmaktadır: Batılı yaklaşıma göre sinema seyircisi tutsak seyircidir (captive audience). Ancak, seyircinin bu tutsaklığı çoğu zaman farkında olunmayan gönüllü bir tutsaklıktır (Kırel, 2012: 29). Pascal Bonitzer (2011: 85) bu mahkûm olma durumunu uç bir önermeye taşıyarak sinema seyircisinin, "Platon' un mağarasındaki esirden çok, Arka Pencere'deki [Rear Window, Alfred Hitccock, 1954] sakata ya da Otomatik Portakal' in [A Clockwork Orange, Stanley Kubrick, 1971] bir koltuğa zincirlenmiş $\square$ olarak karşısındaki sinema perdesine yansitılan korkunç $\square$ ve tiksindirici sahneleri gözlerini kapamadan seyretmek zorunda olan kahramanına" benzediğini ileri sürer. Ancak bizler, seyircinin olağan akışındaki bir dünyada hiçbir zaman için Bonitzer'in Otomatik Portakal filmiyle örneklediği biçimiyle imgelerin akışına mahkûm edildiğini düşünmüyoruz. Bu eğretileme seyircinin öznel bilincini göz ardı ederek, onu iletişimin salt edilgen bir öğesi olarak tasavvur etmektedir. Edilgen izleyici, salonda süregiden gösterinin tahakkümü altındadır ve üstelik gösteri tarafından büyülenmiş durumdadır; kurduğu bağı koparmayı bir an için bile düşünemez, özgürleşmek istemez. Ama diğer yandan Bonitzer'in bu önermesi bize sinemayı bir pencere olarak tasavvur etmenin yolunu da açar ki bu tasavvur seyirciye dair güçlü bir özgürlük potansiyeli de barındırır.

Aslında sinema perdesini ve seyir deneyimini bir pencere olarak tasavvur etmek, onu rüya deneyimiyle özdeşleştiren eğretilemeler kadar erken döneme dayanır. Sinemanın ilk çeyrek yüzyılında Fransız yazınının tipik eğretilemelerinden biri, sinemanın yeryüzünde şeffaf/geçirgen bir pencere açtığına dairdir (Abel, 1988: 17). Hatta Fransız eleştirmen Émile Vuillermoz 7Şubat 1917' deki yazısında sinemayı "hem hayata hem de rüyalara açılan muhteşem bir pencere" olarak nitelendirir (aktaran Abel, 1988: 102). Bu önermeye göre sinema, perde aracılığıyla bir pencere oluşturur. Bu, dünyaya açılan bir penceredir. En azından kuramsal olarak, kurulan bu pencere aracılığıyla bir mekân ve zamanın içine sonsuz sayıda farklı mekân ve zamanı getirmek mümkündür. Bu, farklı mekân ve zamanları, farklı varoluş biçimlerini bir araya getiren, bir bakıma yeni mekânlar ve zamanlar yaratan bir penceredir. Ancak sinema salonunun mekânsal düzenlenişi ve perde, aslında seyircinin hayallerine kapılmasını ya da bir rüyanın içinde savrulmasını engellemektedir. Bir yandan yeni mekân ve zaman bağlamlarını seyirciye sunarken, diğer yandan onu güvenli bir mesafede tutar. "[Bu pencere aracılığıyla kurulan] filmde anlatılan olaylara olan (gerçek ve eğretilemeli) mesafe, sinema salonunun karanlığında oturan izleyici açısından bakma eylemini güvenli kılar" (Elsaesser ve 
Hagener, 2011: 31). Yani bir bakıma seyirci hem pencerenin içinde hem de dışındadır ya da ne pencerenin içinde ne de dişındadır. Pekiyi, bir pencere açan ama aynı zamanda pencereyi de çerçeveleyen, yani onun sınırlarını belirleyen perde muğlaklaşsa ya da sinemasal evrenle fizikî evreni mutlak bir biçimde birbirinden ayıran salonun mekânsal düzenlenişi bu ayrımı olanaksız kılacak biçimde dönüştürülseydi ne olurdu? Ya da şöyle soralım: Tamamen karartılmış bir sinema salonunda tamamen karanlıktan oluşan bir film parçası gösterildiğinde, yani bu örnek için sinemasal evrenle fizikî evren arasındaki sınırları belirleyen ışık tamamen ortadan kalktığında, seyirci de karanlığa gömülüp gerçekliğe tutunmasını sağlayan duyularını yitirmez miydi? Böyle bir varsayımda seyircinin gerçek ve temsili ayırt etmesini sağlayan referansları bulması pek de kolay olmazdı. Ama bir pencere, çoğu zaman için bir mağara ağzı gibi fizikî gerçekliğini algılamanın mümkün olmadığı mekânlardan dişarıya açılmaz. Bunun yerine iki ayrı mekânı ve de gerçekliği bir araya getiren arayüz olarak çalışır. Tam da bu nedenle, Toros yayla köylerindeki seyir deneyiminin, seyircinin gerçeklikle ilişkisini de dönüştürme potansiyeli olan pencereler aracılığıyla kurulduğunu söyleyebiliriz.

Öncelikle şunu belirtmemiz gerekir ki, Toros yayla köylerinde yürüttüğümüz araştırmalar sırasında tespit ettiğimiz gösterim mekânlarının fizikî yapıları, daha ilk elden bir mağara eğretilemesini olanaksız kılmaktadır. David Harvey (2010: 234) mekân bağlamında yorumladığı sinema için, "Sinema ve müziğin birleşmesi, sanatın ve mimarlığın mekânsal pasifliğine karşı etkili bir panzehir oluşturur. Ancak, sinemanın derinliği olmayan bir ekrana ve bir sinema salonuna hapsolmuşluğu, onun da tuhaf bir biçimde mekâna bağlı olduğunu hatırlatan bir şeydir" demektedir. Bu önermesi aslında çalışmamız boyunca soruşturmaya açtığımız geleneksel/konvansiyonel yaklaşımın tüm basmakalıp ifadelerini içermektedir. Sinema, mekânsal olarak sadece Batı' da olduğu biçimiyle düşünülmekte ve kabul edilmektedir. Oysa biz araştırmamız sırasında, Arslanköy ve Kargıpınarı'nda tıpkı şehirlerde olduğu gibi düzenlenmiş sinema salonlarıyla karşılaştık ama hem bu köylerde hem de diğerlerinde, seyyar ya da sabit sinemacılığın gerçekleştirildiği çok çeşitli mekânlara da tanıklık ettik. Örneğin Arslanköy'de An Sineması ve Halkevi Sineması gibi iki salonda film gösterimleri yapılırken, Çınaraltı Kahvehanesi'nin ya da köyün okulunun bahçesinde, açı havada film gösterimleri yapılmaktaydı. Kargıpınarı'ndaki Belediye Sineması'nın 800 koltuklu salonunun üzerinde, yaz aylarında film gösterimlerinin yapıldığı bir teras/dam sineması bulunmaktaydı. Benzer bir teras/dam sinemasıyla Güzelyayla (Kızılbağ) köyünde de karşılaştık ki bu sinema neredeyse Toros dağlarının eteklerine yaslanmıştı; makine dairesinin ardından dağlar yükselmekteydi. Yavca, Tırtar, Değnek, Değirmendere, Dalakderesi, Yeniköy ya da Aladağ gibi onlarca köyde, kahvehanelerde, okul bahçelerinde, köy meydanlarında, bir film gösterimi yapmaya olanaklı hatta kimi zaman olanaksız- hemen her türlü mekânda gösterimlerin gerçekleştiğini saptadık. Gözne ve Ayvagediği'nde olduğu gibi, örneğin Dilek Sineması adıyla faaliyet gösteren ve sadece üç ay için kurulan, geçici yayla sinemalarının hikâyelerini ilk elden dinledik. Etrafı tamamen Toros dağlarıyla çevrilen, adeta bir çanağın tabanında konumlanan ve bu nedenle televizyon yayınlarının sinyali alınamadığı için 1990'ların ortalarına kadar yoğun bir sinemaya gitme deneyiminin yaşandığı Fındıkpınarı'nda aynı anda salon, teras/dam ve bahçe sinemalarının işletildiğini dinledik. Araştırma kapsamında görüştüğümüz Abdullah Demirtaş, çocukluğunu ve gençliğini geçirdiği Fındıkpınarı'nda bulunan bahçe sinemasında, gösterimlerin kavak ağaçlarının altında gerçekleştirildiğini ve kimi zaman ağacın yapraklarının arasında sızan projektör huzmeleriyle adeta büyülendiğini son derece şairane bir biçimde aktarmaktadır (30 Ağustos 2018 tarihli görüşme). Gerek saha ziyaretleri sırasında tespit ettiğimiz gösterim 
mekânları gerekse görüşmelerde aktarılan tanıklıklar bize geleneksel/konvansiyonel sinema mekânlarından son derece farklı gösterim mekânları olduğunu kanıtlamaktadır. Bu mekânların fizikî yapıları, fizikî dünyadan yalıtılmış sinema deneyimini olanaklı kılan kapalı ve karanlık salonların aksine sinema deneyimini fizikî dünyayla bütünleştirmektedir. Ağaçların dallarının arasından sızan projektör huzmeleri, bir okul ya da kahvehanenin kerpiç duvarına gerilen iptidai perde, bir masanın üzerine ya da sehpaya kurulan projektörler, derme çatma makine daireleri, kahvehaneden ödünç alınan sandalyelerle ya da okullardan temin edilen sıralarla kurulan oturma düzeni, çoğu zaman bu sandalyeler ya da sıralar yetmediği için evlerden getirilen kilimlere, yayglara ya da minderlere oturanlar... Oturarak, yatarak, ayakta ya da at sırtında film izleyenler... Tüm bunlar bir mağara eğretilemesi kurmayı zaten olanaksız kılan deneyimlerdir.

Diğer yandan, Toros yayla köylerinde yürüttüğümüz araştırmalar sırasında katılımcıların geçmiş günlerden bir rüya gibi bahsettiklerini sıklıkla gördük ki bu aslında geçmişe duyulan özlemle açıklanabilir. Görüşmecilerimizden seyyar sinemacı Hasan Kınalı sinemayla geçen yıllarını bir rüya gibi anımsadığını ifade ederken, hâlâ seyyar sinemacılık yaptığı günlerin rüyasını gördüğünü ve rüyasında film oynattığını belirtmiştir. Bununla beraber pencere, görüşmelerimizde sıklıkla karşılaştığımız bir olgu olmuştur. Örneğin Ümmiye Koçak çocukluğuna dair seyir deneyimlerini aktarır ve 1970'li yılların ortalarında televizyondan izlediği filmlerin de bu deneyimde önemli bir yer tuttuğunu söylerken, televizyonla kurulan yasak ilişkinin pencere aracılığıyla gerçekleştiğini belirtmektedir. Koçak ve yaşıtı bir çocuk grubu, bir köy evinin hemen bitişiğinde yer alan ve evden bir kapıyla geçilebilen kahvehanenin televizyonunu gizlice izlemektedirler. Kahvehanede zaman zaman kumar oynatıldığı için, eve geçişin sağlandığı kapı sıvayla kapatılmıştır:

"Eve geçmek için de bir teka var, kapı. Kumar oynatılıyor diye kapatmışlar. Küçük kapı, tahtadan. Ama onun üzerinde sıva var. Bizim orada evler çamurla sıvanır. Beyaz. O tahta aralıkları iki, üç milim aralık ya, sıvasını böyle onun bıçakla keserdik, kahvede kışın. Şimdi ev sahibinin kızı var, benim yaşlarımda. O en alta iskemlenin üzerine oturuyor. Bütün böyle delikten bakıyoruz. Üstüne biraz daha yüksek bir sandik geliyor. Benim üzerime, benim üzerime... Pencereye belki o deliklerden emin olun on kişi bakıyor" (Ümmiye Koçak, 13 Temmuz 2018 tarihli görüşme).

Hâlihazırda mekânda pencere açan ekrana, diğer bir pencere aracılığıyla bakmak... Dünyayla, bu pencere aracılığıyla ilişki kurmak... Katılımcılarımızdan bazıları sinemanın özellikle çocuklar için yeni pencereler açtığını söylerken tam da bunu kastetmektedir. Örneğin İbrahim Kalay, 1970'lerde Arslanköy'deki bazı muhafazakâr ailelerin çocuklarına sinemayı yasakladıklarını aktararak nedenini şu şekilde açıklamaktadır:

"[Aileler] o yeniliği kabullenemiyor bir türlü, anlatabiliyor muyum? [Sinema] o çocuğun dünyasında yeni bir pencere açacak, ondan korkuyor belki de bağnaz aile. Yani, çocuk zira onun gündüz -rençper kendisi bahçede- en büyük yardımcısı. Kendi bahçeye gidiyorsa, üç-beş koyunu varsa, koyunu güden de çocuğu. E, belki de onu yapmayacak, sinemaya kaçıp gidecek ileride. Ondan korkuyor. Köyü terk edip gidecek (...) Zira bu sinema herkesin hayatına yeni bir kapı, yeni bir pencere açmıştır. Ufkunu, hayal dünyasını geliştirdi çocukların" (İbrahim Kalay, 18 Temmuz 2018 tarihli görü̈sme).

Henüz bir çocukken Arslanköy'de, An Sineması'ında film izleyen Sami Dündar da o 
yıllarda çocukların sinemayla kurdukları ilişkiyi benzer bir eğretilemeyle aktarmaktadır:

\begin{abstract}
“Benim hissettiğim şuydu: Dünya görüşün bir kere açıllyor. İnsanların diksiyonlarn o dönemde yerleşiyor. Arslanköy farkh bir konuşma kültürüne sahiptir (...) Kültürünüz farklı, dünya görüşünüz farklı, işte sadece yaşadığınız alanın Arslanköy'den ibaret olmadığını, farklı farklı kelime dağarcıklarınızın geliştiğini görüyorsunuz (...) [Sinema] Yeni bir dünya açardı insanlara" (Sami Dündar, 26 Temmuz 2018 tarihli görüşme).
\end{abstract}

Bu bağlamda son olarak, katılımcılarımızdan Sabri Şenevi'nin Umut filminin (Yılmaz Güney, 1970) çekimleri sırasında Yılmaz Güney'le tanışmasının hikâyesini ve yönetmenin kendisine öğüdünü aktarmalıyız. Şenevi, Umut'un çekimleri sırasında henüz bir çocuktur ve her Adanalı çocuk gibi hem Güney'i hem de sette neler olup bittiğini merak etmektedir. Bir gün, Adana çarşısında gerçekleştirilen çekimler sırasında, esnaf olan amcası Şenevi'ne sete gidip Yılmaz Güney'i çağırmasını söyler; yönetmene dükkânında kahve ikram etmek istemektedir. Şenevi hemen sete gider ve çekimlere ara verildiğinde Güney'e amcasının teklifini iletir. Güney kabul eder ve amcasının dükkânını ziyaret eder; kahveler içilirken de konu Şenevi'nin sinema sevgisine gelir. Amcası Şenevi'nin sinemayı çok sevdiğini, bir filmden diğerine koşup durduğunu ve sinema sevdası yüzünden kendisini evde ya da dükkânda zapt etmenin mümkün olmadığını anlatır. Güney, Şenevi'ne döner ve kendi filmlerini de izleyip izlemediğini sorar. Şenevi, tüm filmlerini izlediğini ve bazılarının çok etkisinde kaldığını söyler. Yılmaz Güney, Şenevi'nin sözünü bitirmesini bekler ve sonra konuşur: “Oğlum, sinema çok güzel bir şeydir, sinemayı sev. Hayatı sinema öğretir, sen de hayatı sinemadan öğren. Sinema dünyaya açılan bir penceredir. Önemli olan ise, o pencereden nasıl baktığındır" (Güney'den aktaran Sabri Şenevi, 13 Aralık 2018 tarihli görüşme). Evet, sinema bir penceredir ve bu pencere bize hem zamana hem de mekâna dair sonsuz bir özgürleştirici bakış olană̆1 sağlar.

\title{
Sonuç: Yeni(den) Bakma Biçimleri
}

"Seyirci, anlamadan önce hissetmeye hazır olduğunda, ona her şeyi gösteren ve anlatan öyle çok film var ki!"

Bresson, 2012: 63

Toros yayla köylerinde, özellikle 1960-1980 döneminde gerçekleşen sinema deneyimlerini irdelemeye çalıştığımız bu araştırmanın sonuçlarından ilki, sinemanın şehir ve modernlikle ilişkisine ve seyir deneyimlerine dair Batılı geleneksel/konvansiyonel yaklaşımların sunduğu önermelerin araştırmanın kapsadığı dönem ve coğrafya için pek çok açıdan tartışmalı olduğuna dairdir. Batılı geleneksel/konvansiyonel yaklaşım Toros yayla köylerinde vuku bulan sinema(cllı) etkinliklerini ve seyir deneyimlerini öngörmediği gibi, bu etkinlikleri ve deneyimleri açıklamaktan da uzaktır. Bu uzaklık bize Toros yayla köylerindeki seyir deneyimleri bağlamında açıklamamız gereken bir dizi olgu sunar: Öncelikle Toros yayla köylerinde görüldüğ ü üzere geleneksel/konvansiyonel yaklaşımın önerdiği biçimde, sinema şehirle birlikte var olmak zorunda değildir; şehirden bağımsız sinema deneyimlerinin de, üstelik güçlü bir biçimde gerçekleştiği coğrafyalar olmuştur. Yine buna bağlı olarak şehir, sinema ve modernlik ilişkisi üçlü bir koşula dayanan simbiyotik bir ilişki de olmak zorunda değildir. Modernlik de, tıpkı sinema gibi farklı coğrafyalarda şehirlerin dışında deneyimlenen bir olgudur. Bu noktada modernliği Marshall Berman'ın önerdiği biçimde değerlendirmek, 
Toros yayla köylerinde gerçekleşen deneyimi açıklamakta yarar sağlayabilir. Berman, “Modern olmak, kişisel ve toplumsal yaşamı bir girdap deneyimi gibi yaşamak; insanın kendini ve dünyasını sürekli bir çözülüş, yenilenme, sıkıntı, kaygı, belirsizlik ve çelişki içinde bulmasıdır" der: "Kısaca, katı olan her şeyin ergiyip havaya karıştığı bir evrenin parçaları olmak... Öte yandan bir modernist olmak, insanın kendini bu girdabın içinde bile bir şekilde evinde hissetmeyi başarması, bu girdabın ritimlerini özümsemesi; bu girdabın akıntıları arasında, mahvedici akışının ortaya çıkmasına izin verdiği gerçeklik, güzellik, özgürlük ve adalet biçimleri arayışında olmak demektir" (Berman, 1994: 460). Toros yayla köylerinin sakinlerinin topyekûn bir gerçeklik, güzellik, özgürlük ve adalet biçimleri arayışında olduklarını tabii ki iddia edemeyiz. Ancak araştırmalarımız sırasında, sinemayla birlikte tüm bu duyguların az ya da çok deneyimlendiğine tanıklık ettik. Dolayısıyla artık şehir, sinema ve modernlik ilişkisine dair yeni bakış açılarına ihtiyacımız var.

Bununla beraber, geleneksel/konvansiyonel yaklaşımın sinemacılık etkinliklerine ve seyir deneyimlerine dair ön kabullerini ve peşin hükümlerini de gözden geçirmemiz gerekmektedir. Toros yayla köylerinde seyir, Batılı şehirlerde olduğu gibi birörnek gösterim mekânlarında, birörnek etkinliklerle gerçekleşmemiştir. Gösterimler sinema salonlarının yanı sıra, şehirlerde örneklerine nadir rastlanır biçimde, teras/dam sinemalarında, bahçelerde, yaylalara kurulan geçici gösterim mekânlarında, köy meydanlarında, kahvehanelerde, çay bahçelerinde ve okullarda yapılmıştır. Gösterimler için çoğu zaman sabit, yerleşik sinema mekânları değil, sürekli değişen yerler ve mekânlar kullanılmıştır. Bununla birlikte gösterimi gerçekleştirenler de hareketlidir; bölgedeki pek çok köyde ve yaylada sinemacılık seyyar biçimde icra edilmiştir. Toros yayla köylerindeki sinema deneyimi, geleneksel/konvansiyonel yaklaşımın önermelerinden farklı olarak hemen her öğesiyle hareketliliğe göndermede bulunmaktadır: Öncelikle gösterilen filmin kendisi ilk elden harekete göndermede bulunur. Gösterimi gerçekleştiren sinemacı da hareketlidir; belli bir mekânda yerleşmek yerine belli izlekler üzerinde gösterimleri gerçekleştirir. Bu açıdan seyyar sinemacı belli köyleri birbirine bağlayan bir ağ oluşturur. Nihayetinde seyirci de hareketlidir; gösterimin gerçekleştirileceği köye, yakın köylerden, mahallelerden ya da yaylalardan gelinir. Bu mekânlardaki gösterimler ise, Batılı şehirlerdeki örneklerin aksine, kapalı ve fizikî gerçeklikten yalıtılmış mekânlarda değil, açık ve fizikî gerçeklikle iç içe geçmiş mekânlarda yapılmıştır. Üstelik yine Batılı örneklerin aksine sükûnet içindeki birörnek seyir deneyiminin yerini gürültülü ve performatif seyir deneyimi almıştır. Seyirci son derece "disiplinsiz" ama aynı zamanda filmle karşı karşıya geldiğinde bir o kadar da etkindir. Bu farklılıklar bizi seyir deneyimini geleneksel eğretilemelerle değil de yeni bakış açılarıyla değerlendirmemiz gerektiğine taşımaktadır. Nihayetinde sinema, çoğu zaman durağanlıkla itham edilen "taşrayı" son derece devingen bir mekân olarak yeniden örgütlemiştir ve dolayısıyla şehir dışındaki sinemayı geleneksel/konvansiyonel yaklaşımın önermeleriyle değerlendirmek mümkün değildir. Bu yüzden Sepil Kırel'in de dikkat çektiği gibi, sinema ile ilgili akademik çalışmalarımızda kuramsal yaklaşımlardan yararlanırken özenli bir tutum içinde olmamız gerektiği ortaya çıkmaktadır: "Batı'da üretilen kuramsal zeminin her kültüre ait sinemasal olguları açıklamakta yararlı anahtarlar olamayacağı açıktır" (Kırel, 2012: 38). Sinema tarihini ve seyir deneyimlerini çözümleyebilmek için yeni bakışlara, yeni yaklaşımlara ihtiyacımız var. Bu, pekâlâ "kendi içine kapalı bir sinemasal kuram arayışı yerine kuramsal zemine eleştirel biçimde bakabilmekle" (Kırel, 2012: 38) sağlanabilir ama aynı zamanda araştırmacılar olarak bakışımızı, yaklaşımımızı dönüştürecek saha deneyimlerine, deneyimlerimizi değerlendirmemize, çözümlememize, yorumlamamıza ve aktarmamıza olanak sağlayacak yeni kavramlara ve kavram setlerine de ihtiyacımız olduğu açıtır. 


\begin{tabular}{|l|l|}
\hline Geleneksel / Konvansiyonel Yaklaşım & Yeni Yaklaşım \\
\hline Sinema, şehir ve modernlik ilişkisi & Şehirden bağımsız sinema deneyimi \\
\hline Birörnek gösterim mekânları ve gösterim pratiği & $\begin{array}{l}\text { Salon sinemaları, teras/dam sinemaları, bahçe } \\
\text { sinemaları, yayla sinemaları, köy meydanları, } \\
\text { kahvehaneler, çay bahçeleri, okullar... }\end{array}$ \\
\hline Sabit, yerleşik sinema mekânları ve gösterim & Hareketlilik ve seyyar sinema \\
\hline $\begin{array}{l}\text { Kapalılık ve fizikî gerçeklikten yalıtılmış sinema } \\
\text { salonları }\end{array}$ & $\begin{array}{l}\text { Açıklık ve fizikî gerçeklikle iç içe geçmiş sinema } \\
\text { mekânları }\end{array}$ \\
\hline $\begin{array}{l}\text { Genellikle sükûnet içindeki birörnek seyir(ci) ve } \\
\text { disiplinli seyir }\end{array}$ & $\begin{array}{l}\text { Gürültülü ve performatif seyir(ci); farklı seyir } \\
\text { pratikleri }\end{array}$ \\
\hline Rüya ya da mağara eğretilemesi & Pencere eğretilemesi \\
\hline
\end{tabular}

Tablo 1: Modernlik, Şehir, Sinema ve Seyirci İlişkilerine Dair Geleneksel/Konvansiyonel Yaklaşıma Karşllk Yeni Bir Yaklaşım Önerisi

Hindistan sinemalarında vuku bulan seyir deneyimlerini etnografik yöntem(ler)le araştıran Lakshmi Srinivas, ülkesindeki film çalışmalarının, popüler sinemaya yabancılaşmış ve onu halk kültürü olarak gören eğitimli orta-sınıf araştırmacıların öncülügüunde yürütüldügüünü söyler (2002: 156). Araştırmacıların sinema sanatına dair öznel ilgileriyle, yaygın biçimde vuku bulan seyir deneyimi ve seyirciler arasındaki mesafe, iki grup arasındaki ilgi ve ilişkiyi neredeyse olanaksız kılmaktadır. Srinivas'ın bu saptaması, Türkiye' deki film araştırmalarının bazı önemli sorunlarını da açıklamaktadır. Ulusal sinema çalışmalarımızın çoğunlukla filmleri ve/veya yönetmenleri merkeze alması, bu çalışmaların sadece filmleri, yönetmenleri, akımları ya da türleri kapsayacak biçimde, aslında film çalışmasına dönüşmüş olması; ulusal sinema tarihimizin merkezine İstanbul'un oturtulması; sinema tarihimizle ilgili çoğu çalışmanın özgünlükten uzaklaşarak tekrara düşmesi ve birincil kaynaklar yerine ikincil kaynaklarla gerçekleştirilmesi bu temel sorunlardandır. Bunlarla beraber, seyircinin de tıpkı araştırmacı gibi orta-üst sınıftan müteşekkil ve mutlaka şehirli bir kitle olduğuna dair ön kabul, Batılı geleneksel/konvansiyonel önermelerin sinemayla ilgili hemen her meselenin açıklanması için tek yaklaşım olarak benimsenmesiyle birleştiğinde, toplumu ve toplumsal deneyimleri açılamaktan uzak ve hatta ona yabancılaşmış bir araştırma ekolünün ve araştırmacı öbeğinin oluşmasına yol açmıştır. Oysa bugün, filmler ya da yönetmenlerle beraber seyircinin ve seyir deneyimlerinin de yapının temel öğelerinden olduğunu görmekteyiz. Aynı biçimde İstanbul'un dışına çıkarak bir "yerel sineması çalışmalarına" girişilmesi gerektiğini de. Tüm bunları gerçekleştirmek için ise, Toros yayla köylerinde yürüttüğümüz araştırmanın hemen ilk günlerinden itibaren tanıklık ettiğimiz üzere, yeni bakışlara ihtiyacımız olduğunu görmekteyiz. Araştırmanın yürütüldüğü bölgede, 1960-1980 yılları arasında gerçekleşen ve muhtemeldir ki farklı coğrafyalarda farklı dönemlerde vuku bulan seyir deneyimlerini değerlendirmek için yeni tanımlara ihtiyacımız var. Ortaya yeni tanımları koymalıyız, yeni sorular sormalıyız ve araştırmalarımız için yeni yöntemler geliştirmeliyiz. Olguları açılayabilmek için yeni alegorilere, eğretilemelere, kavramlara ve kavram setlerine ihtiyacımız var; yazmak için de öyle. Yeni bakışlara ihtiyacımız var. Robert Bresson (2012: 63), herhangi bir seyircinin herhangi bir filmi anlamaya girişmeden önce onu hissetmeye çalışmasının önemli olduğunu söylemektedir. Seyirci hissetmeye hazır olduğunda, film ona her şeyi gösterecek ve anlatacaktır. Biz, Bresson'un bu önermesini sinema araştırmaları ve sosyal bilimler çerçevesinde yeniden kurmayı öneriyoruz: "Araştırmacı hazır ise, seyircinin ona sunacağı çok şey olacaktır." 


\section{Teşekkürler}

Bu çalışma, Çukurova Üniversitesi İletişim Fakültesi - Radyo, Televizyon ve Sinema Bölümü öğrencilerinden Hande Canbolat, Eren İlbuğa, Necati Öz, Elif Şimşek ve Yıldırım Yeniçeri' nin büyük katkılarıyla gerçekleştirilmiştir; kendilerine teşekkürü borç biliriz.

\section{Kaynakça}

Abel, Richard. (1988). French Film Theory and Criticism - A History / Antology 1907-1939 Volume I: 1907-1929. New Jersey: Princeton University Press.

Akbulut, Hasan. (2017). “Cinemagoing as a Heterogeneous and Multidimensional Strategy: Narratives of Woman Spectators". The Turkish Online Journal of Design Art and Communication, 7(4), s. 530-541.

Akbulut, Hasan. (2018). "Bir Seyirci Araştırmasından Etnografik Deneyimler ve Hikâyeler". Folklor/ Edebiyat, 95(24), s. 13-34.

Akçura, Gökhan. (2004). Aile Boyu Sinema - Ivır Zıvır Tarihi 7. İstanbul: İthaki Yayınları.

Andersen, Nethan. (2014). Shadow Philosophy: Plato's Cave and Cinema. Londra \& New York: Routledge.

Aydın, Hakan. (2008). “Sinemanın Taşrada Gelişim Süreci: Konya'da İlk Sinemalar ve Gösterilen Filmler (1910-1950)". Selçuk Üniversitesi Sosyal Bilimler Enstitüsü Dergisi, 19, s. 61-74.

Benjamin, Walter. (2007). Pasajlar (6. Baskı). A. Cemal (çev.), İstanbul: Yapı Kredi Yayınları.

Berman, Marshall. (1994). Katı Olan Her Şey Buharlaşıyor - Modernite Deneyimi. Ü. Altuğ ve B. Peker (çev.), İstanbul: İletişim Yayınları.

Biltereyst, Daniël. \& Philippe Meers. (2016). New Cinema History and the Comparative Mode: Reflections on Comparing Historical Cinema Cultures. Alphaville: Journal of Film and Screen Media, 11, s. 13-32.

Biltereyst, Daniël, Richard Maltby \& Philippe Meers. (Eds.) (2019). The Routledge Companion to New Cinema History. New York: Routledge.

Biryıldız, Esra. (2004). "Kent Dışında Sinema", N. Türkoğlu, M. Öztürk \& G. Aymaz, (der.), Kentte Sinema Sinemada Kent, İstanbul: YeniHayat Yayıncılık, s. 53-55.

Bonitzer, Pascal. (2011). Kör Alan ve Dekadrajlar (2. Bask1). İ. Yasar (çev.), İstanbul: Metis Yayınları.

Botz-Bornstein, Thorsten. (2011). Filmler ve Rüyalar - Tarkovski, Bergman, Sokurov, Kubrick ve Wong Kar-wai. C. Soydemir (çev.), İstanbul: Metis Yayınları.

Braudel, Fernand. (2016). Tarih Üzerine Yazılar. M. A. Kılıçbay (çev.), Ankara: Doğu Batı Yayınları. 
Bresson, Robert. (2012). Sinematograf Üzerine Notlar. N. Güngörmüş (çev.), İstanbul: Küre Yayınları.

Brownlow, Kevin. (1968). The Parade's Gone By... Londra: Secker \& Warburg.

Caunce, Stephen. (2001). Sözlü Tarih ve Yerel Tarihçi. B. B. Can \& A. Yalçınkaya (çev.), İstanbul: Tarih Vakfı Yurt Yayınları.

Elsaesser, T. ve Hagener, M. (2011). Film Kuramı - Duyular Yoluyla Bir Giriş. B. Soner ve B. Yıldırım (çev.), Ankara: Dipnot Yayınları.

Ertaylan, Arzu. (2013). "Yeşilçam Döneminde Van'ın Sinema Kültürü". Turkish Studies: International Periodical For The Languages, Literature and History of Turkish or Turkic, $8(8)$, s. 1839-1857.

Evren, Burçak \& Karadoğan, Ali. (2008). Sinemada Son Adam: Makinist Ramazan Çetin - Ankara Sinemalarn Tarihi. Ankara: DKIV Yayınları.

Gennari, Daniela Treveri, Danielle Hipkins, \& Catherine O'Rawe. (2018). Rural Cinema Exhibition and Audiences in a Global Context. Londra: Palgrave Macmillan.

Harvey, David. (2010). Postmodernliğin Durumu - Kültürel Değişimin Kökenleri (5. Bask1). S. Savran (çev.), İstanbul: Metis Yayınları.

Hauser, Arnold. (1995). Sanatın Toplumsal Tarihi (2. Baskı). Y. Gölönü (çev.), İstanbul: Remzi Kitabevi.

Hobsbawm, Eric J. (1999). İmparatorluk Çağı 1875-1914. V. Aslan (çev.), Ankara: Dost Kitabevi Yayınları.

Karagözoğlu, İnal. (2004). Ankara'da Sinemalar Vardı. İstanbul: Bilişim Yayınevi.

Kaya, Dilek. (2017). “Eski İzmir Sinemalar ve Yıldız Sineması: Mekân, Toplum, Seyir". Sinecine: Sinema Araştırmaları Dergisi, 8(2), s. 93-138.

Kırel, Serpil. (2012). Kültürel Çalışmalar ve Sinema (2. Baskı). İstanbul: Kırmızı Kedi Yayınevi.

Le Roux, Cheryl. (2015). "Oral history research ethics: should anonymity and confidentially issues be dealt with on their own merit?". Africa Education Review, 12(4), s. 552-566.

Liman, Ali Sait. (2014). “Gaziantep'te Sinema, Seyir ve Seyirci (1923-1980)”. İstanbul Üniversitesi İletişim Fakültesi Dergisi, 47, s. 97-123.

Makal, Oğuz. (2002). Tarihin Penceresinden İzmir Sinemaları (1909-1930). İzmir: Alo Bilgi Kültür Yayını.

Maltby, Richard, Melvyn Stokes, \& Robert Clyde Allen (Eds). (2007). Going to the Movies: Hollywood and the Social Experience of Cinema. Exeter: University of Exeter Press. 
Maltby, Richard, Daniël Biltereyst, \& Philippe Meers (Eds). (2011). Explorations in new cinema history: approaches and case studies. Chichester, UK: Wiley-Blackwell.

Mungan Yavuztürk, Gülseren. (2013). “Ankara'da Yayımlanmış Sinema Dergilerinin Kısa Tarihçesi". Ankara Araştırmaları Dergisi, 1(2), s. 79-92.

Oğuz, Remzi. (2014). 1924 Adana Ticaret Rehberi. H. Altıparmak (çev.), Adana: Adana Ticaret Odası Yayınları.

Orr, John. (1997). Sinema ve Modernlik. A. Bahçıvan (çev.), Ankara: Bilim ve Sanat Yayınları.

Özkan Altınöz, Meltem. (2015). “Endüstri Kenti Karabük'ün Sosyal Yaşantısının Şekillenişinde Yenişehir Sineması'nın Rolü". Itobiad: Journal of The Human \& Social Science Researches, $4(1)$, s. 83-99.

Öztürk, Mehmet. (2007). Sine-Masal Kentler - Modernitenin İki "Kahraman"ı Kent ve Sinema Üzerine Bir İnceleme. İstanbul: Donkişot Yayınları.

Öztürk, Serdar. (2013). “Türkiye'de Sinema Mekânlarım Sözlü Tarih Üzerinden Anlamak”. Millî Folklor, 98, s. 19-31.

Öztürk, Serdar. (2018). Sinema Felsefesine Giriş - Film-Yapımı Felsefe. Ankara: Ütopya Yayınevi.

Özuyar, Ali. (2013). Türk Sinema Tarihinden Fragmanlar (1896-1945). Ankara: Phoenix Yayınları.

Özyılmaz, Özge. (2016). "Türkiye'de Sesli Filme Geçiş". Alternatif Politika Dergisi Sinema Özel Sayısı, s. 30-54.

Pezzella, Mario. (2006). Sinemada Estetik. F. Demir (çev.), Ankara: Dost Kitabevi Yayınları.

Srinivas, Lakshmi. (1998). "Active viewing: An ethnography of the Indian film audience". Visual Anthropology, 11(4), s. 323-353.

Srinivas, Lakshmi. (1999). Movie Magic: An Ethnography of the Cinematic Experience. Unpublished PhD Dissertation, University of California, Los Angeles.

Srinivas, Lakshmi. (2002). "The active audience: spectatorship, social relations and the experience of cinema in India". Media, Culture \& Society, 24, s. 155-173.

Şahin, Osman. (1974). “Toros Dağlan'nda Sinema Soruşturması”. Yedinci Sanat, 19, s. 50-53.

Şahin, Osman. (1996). “Toroslar'da Sinema Çerçileri”. Dinçer, S. M. (der.). Türk Sineması Üzerine Düşünceler. Ankara: Doruk Yayınları, s. 301-307.

Türk Dil Kurumu - Güncel Türkçe Sözlük. www.tdk.gov.tr. Erişim Tarihi: 10 Ocak 2019.

Uçar İlbuğa, Emine. (2017). “1960-1970'li Yillarda Kentve Taşra Karşıtlığında Türkiye’de Kadınların Sinema İzleme Pratikleri Üzerine Bir Araştırma". İletişim Kuram ve Araştırma Dergisi, 45 , s. 388-402. 
Uçar İlbuğa, Emine. (2018). “1960-1970'li Yillarda Antalya'da Sinema İzleme Deneyimi”. İlef Dergisi, 5(1), s. 61-90.

\section{Görüşmeler}

Abdullah Demirtaş ile 30 Ağustos 2018 tarihinde gerçekleştirilen görüşme.

Bilal Ay ve Fatma Ay ile 13 Temmuz 2018 tarihinde gerçekleştirilen grup görüşmesi.

Emine Yıldız ile 13 Temmuz 2018 tarihinde gerçekleştirilen görüşme.

Fatma Ay ile 13 Temmuz 2018 tarihinde gerçekleştirilen görüşme.

Hasan Kınalı ve Hayriye Kınalı ile 30 A ğustos 2018 tarihinde gerçekleştirilen grup görüşmesi.

İbrahim Kalay ve Maide Kalay ile 18 Temmuz 2018 tarihinde gerçekleştirilen grup görüşmesi.

Memnune Kizir ile 13 Temmuz 2018 tarihinde gerçekleştirilen görüşme.

Sabri Şenevi ile 13 Aralık 2018 tarihinde gerçekleştirilen görüşme.

Sami Dündar ile 26 Temmuz 2018 tarihinde gerçekleştirilen görüşme.

Sinan Öz ile 28 Ağustos 2018 tarihinde gerçekleştirilen görüşme.

Ümmiye Koçak ile 13 Temmuz 2018 tarihinde gerçekleştirilen görüşme. 